\title{
Financial Innovations and Technologies: Indian Economy 2020
}

\author{
Sweety Gupta and Aanchal Aggarwal \\ Assistant Professor, \\ Rukmini Devi Institute Of Advanced Studies, Affliated To Guru Gobind Singh Indraprastha University, Delhi
}

\begin{abstract}
Financial innovation is not a new phenomenon as it has a long history of success and proven benefits that have had great impact on the Indian economy. Innovation is a broadly positive force within financial services. In this paper we have made an effort to describe the recent financial innovation changes taking place in India. In this paper we have discussed the impact of these financial innovations on the structure and behavior of financial markets and the Indian economy. There are also many financial innovations that have had a significant positive effect on the economy like Venture Capital, microfinance and also various financial technologies like National Electronic Fund Transfer (NEFT), Mobile-Banking. Online share trading, E-banking have played a significant role in changing India. With time all these innovations have become a crucial part of India and have brought many improvements in the financial environment of the country necessary to meet the needs of present global turbulent financial environment. To achieve the objectives of making India a superpower in 2020, appropriate efforts should be taken to promote the innovations in the financial sector for continued growth and development that leads the country to a path of becoming a superpower as these innovation and technologies drive economic growth and increase standards of living.
\end{abstract}

Keywords: Innovation, Technology, Indian economy, financial environment, economic growth.

\section{Introduction}

The current scenario of Indian economy cannot be extant until it is supported by an efficient financial system. The financial system can be defined as a cluster of markets, institutions, instruments and regulations through which the financial securities are traded, interest rates are determined and financial services are produced and delivered around the world. The financial system is considered as the most innovative creation of the modern society.

The term innovation can be defined as the emergence of new ideas that brings a change in the system. These ideas can be in the form of new concepts, solutions to problems and instruments that can be implemented in order to change and improve the conditions or situations of a business entity. A business entity or an organization cannot have a sustainable growth without innovation management followed by trust, reputation, knowledge and experience.

Financial innovation is the act of creating new financial instruments and then wide spreading with new financial technologies into the markets. Financial innovations are classified as product or process variants. Variants of product include new derivations, new securities and new forms of pooled ventures or investments but process variants include distribution of securities, transaction processing etc.

Financial innovations are broadly classified into three categories. These are based on whether they (a)facilitate the transfer of value through time; (b) allow the ability to contract on future values; and (c) permit the negotiability of claims. Merton's and Crane et al identifies some functions that are performed by financial innovations. These can be briefed as mutual funds, saving accounts, cashless banking, contracting by venture capital firms, risk management etc.

Financial system is the integrated part of our global economic system. It analyses and determines the cost and flow of funds that are moving in the system for daily transactions. It acts as a convenient source of movement of funds between various economic entities like households, small business enterprises, governments and other financial institutions.

Many financial innovations have given origin to financial technologies such as automated teller machines and risk management products, National electronic funds transfer, mobile banking, etc. The main aim of this paper is to analyze the concept of financial innovations along with financial technologies. The paper will examine the current scenario of Indian financial system and recent innovations in financial sector. The paper is also an attempt to show the scope of financial innovations and technologies in India by 2020.

Financial innovations act as a contrivance to finance technological projects when traditional sources of finance are not available due to high risks of investments. On the other hand the economy is progressing technologically which results in complexity of business processes and new types of risk which forces the financial system to adopt the changes. 


\section{Survey Of Literature}

Schumpeter (1942) states that large firms prefer to go for innovation due to two main reasons. First, Research \& development projects usually involve huge expenses that can only be recovered with exhaustive sales. They enjoy scale and scope economies in the process of innovation and have relatively better access to external monetary resources. Comparing the two, Scherer and Ross (1990) suggested that smaller firms may be more comfortable to become rapid innovators if Research \& Development in larger firms is undermined by loss of managerial control and/or a bureaucratic approach to innovation.

In a theoretical model developed by Aron and Lazear (1990), new (or start-up) firms are more likely to initiate new research programs and introduce new products that may result in higher profits over the longer term. Another factor that is differentiating new and existing firms is Cannibalization. Unlike new firms, incumbents must consider potential lost revenues from sales of an existing product if it is a near-substitute for the innovation. An existing firm might also suffer if the cost of producing the current product is adversely affected by the introduction of a new one, possibly causing scope diseconomies.

Boot and Thakor (1997) use a theoretical model to illustrate that the probability of innovation in the financial sector rises with specialization (boutique firms) and competition. Bhattacharyya and Nanda (2000) show that higher market share and more developed client relationships increase the incentive of investment banks to innovate.

Technological shocks stimulate innovation: Shocks to technology are thought to provide a "supplyside" explanation for the timing of some innovations. IT and other inventions and innovations in telecommunications (and more recently the Internet) has facilitated a number of innovations (not all successful), including new methods of underwriting securities (e.g., OpenIPO), new methods of assembling portfolios of stocks (folioFN), new markets for securities and new means of executing security transactions. White (2000) articulates this technological view of financial innovation.

New "intellectual technologies," i.e., derivative pricing models, are credited with stimulating the growth and popularization of a variety of new contracts. Many new forms of derivatives were made possible because business people could have some confidence in the methods of pricing and hedging the risks of these new contracts. Different forms of innovations such as new risk management systems and measures (such as Valueat-Risk based measures), on-line retirement planning services (like Financial Engines), and new valuation techniques (like real options) clearly were facilitated by both intellectual and information technology innovations.

\section{FINANCIAL TECHNOLOGIES \& INNOVATIONS}

In the late 90s, the emergence of New Industrial Policy opened door for many financial innovations and technologies. These innovations have proved their significance over time and are an important aspect of today's financial environment. Some of the innovations that have changes the way we do business are discussed below:

\section{Venture Capital}

Venture Capital is the fund or initial capital provided to businesses at start-up stage for new ideas to small firms with good growth potential. Venture Capital is considered to be a significant source of funding for startups that are not able to get sufficient finance from trusted sources. Since the risk involved in funding venture capital is high, the returns from the investment in startups can also be rewarding. One of the most important factors influencing the returns to the venture capitalists is the growth prospect of the company. Besides getting good returns, venture capitalists also obtain the power to influence the decisions of the companies they have invested their money in. Further, the venture capitalist who is investing his money may not have any business experience associated with the industry. Venture capital can come from a group of wealthy investors, investment banks and other financial institutions. Venture Capital is increasingly getting popular among small start up firms or companies which cannot raise funds by issuing debt.

\section{Microfinance}

"Microfinance typically refers to a range of financial services including credit, savings, insurance, money transfers, and other financial products provided by different service providers, targeted at poor and lowincome people."

Microfinance is the provision of financial services to low-income clients, including individuals and groups, who traditionally lack access to banking and related services due to low earning and growth potential.Micro finance is an effective in reducing poverty, empowering women and leads to economic growth and development.

Microfinance plays a very crucial role in empowerment of women. Traditionally, women were not actively able to participate in the economic activity of households especially those in underdeveloped countries. But 
microfinance aims to provide women with the financial services to start business ventures and actively participate in the economic activities. Microfinance has given them confidence, improved their status and increased their involvement in decision-making process, thereby reducing gender inequality.

Micro Finance is emerging as a powerful instrument for poverty alleviation in the new economy especially for women. In India, microfinance industry is dominated by Self Help Groups (SHGs) that aimed at providing a cost effective mechanism for providing financial services to the individuals and groups as they lack access to financial services because of low incomes of their businesses.

\section{NEFT}

According to Reserve Bank of India, National Electronic Funds Transfer (NEFT) is a nation-wide payment system to facilitate one-to-one funds transfer. Under NEFT, individuals, firms and corporates can electronically transfer funds from any bank branch to any individual, firm or corporate having an account with any other bank branch in the country participating in the Scheme.

The funds under NEFT can be transferred by individuals, firms or corporates maintaining accounts with a bank branch. Even individuals not having a bank account can deposit cash at the NEFT-enabled branches with instructions to transfer funds using NEFT. However, such cash remittances will be restricted to a maximum of Rs.50,000/- per transaction. Such walk-in-customers have to furnish full details including complete address, telephone number, etc. NEFT, thus, also help in transfer of funds even without having a bank account. This is a simple, secure, safe, fastest and cost effective way to transfer funds especially for Retail remittances.

The advantages offered by NEFT over other modes of funds transfer are:

- There is no need of physical cheque or Demand Draft while transferring money.

- Since the transfer of the fund is electronic, there is no need to visit bank for depositing the paper instruments as in the case of Cheque and Demand Draft.

- The chances of fraud in case of NEFT are very low as compared to traditional lodes of money transfer like Cheque and Demand drafts that can be lost or stolen easily.

- NEFT is very cost effective and save you the time also.

- Credit confirmation of the money transferred can also be received via SMS or email.

- The person transferring the money can easily transfer the funds from the comfort of their homes using internet banking.

- NEFT makes possible real time transfer of funds possible in a secure manner.

ATM

Automatic teller machine (ATM), is a computerized telecommunications device that provides Bank customers to have access to financial transactions without the need of visiting the bank with the help of ATM Machines and plastic cards.

ATMs can be used by customers to have access to bank accounts in order to make cash withdrawals or check account balances. ATMs can be found easily in cities, allowing customers easier access to their accounts. Using a ATM operated by your bank is generally free of cost, but using ATM operated by a competing bank may involve a small fee.

\section{Advantages of Automated Teller Machines (ATMs)}

1. ATM provides 24 hours service and convenience to bank's customers as you can withdraw cash at any time of day and night.

2. ATM reduces the workload of bank's staff and provide service to bank's customer without any error.

3. ATM is very beneficial for travelers as it makes it possible to carry money in plastic form that is safer and more secure. The traveler's can withdraw cash at ATMs in foreign countries.

4. ATM may give customers new currency notes and maintain the privacy in banking transactions as the ATM card is protected by a PIN.

5. ATMs offer the convenience of multiple locations as they are scattered all over the country. You can withdraw cash at any bank that is part of the system to which your ATM card is linked without being part of any long queues.

\section{Mobile Banking}

Mobile banking is a system that allows one to conduct a number of financial transactions through a mobile device such as a phone.

Mobile Banking in increasingly getting popular with the increasing use of smartphone and it is becoming very successful with time. 


\section{Advantage of Mobile Banking}

1:-Mobile Banking uses the network of service provider and it doesn't need internet connection which makes it a convenient \& cost effective option in developing countries like India where there are less internet connection.

2:-Mobile Banking is can be used 24*7 and it is convenient mode for many users and it is more secured and risk free compared to online or internet Banking.

4:-With the help of Mobile Banking you can avail many services like paying bills, funds, check account balance, review your recent transaction, ATM card etc.

\section{KEY DRIVERS FOR FINANCIAL INNOVATIONS TO BE SUCCESFUL IN LONG RUN}

Financial innovations once implemented are not sure of being successful in long run. There should be certain key drivers to make it stand in the long run as well. Five factors should be taken into considerations to make a financial innovation successful in long run:

$\checkmark$ Well trained human capital.

$\checkmark$ Smooth flow of investments into the market to facilitate future innovation efforts.

$\checkmark$ Development of technological leadership.

$\checkmark$ Ability to adapt to changes in innovation projects in financial markets.

$\checkmark$ Facing dynamism in public support systems for innovations.

Firstly, there should be high skilled man power or human capital with expertise knowledge of the particular financial innovation to deal with day to day technical problems.

Secondly, investments which can be done now but are not made can have negative effects in the future as the pool of opportunities will be reduced due to limited investments. Therefore, tacit knowledge should be possessed by the investors in order to avoid such losses and negative effects and proper Research \& Development should be done keeping in view the future prospects.

Third, technological leadership should be preserved as key businesses which are located abroad may respond to low demand of local markets and also difficulties in financing may occur. Partial relocations of companies should be avoided to hinder the unequal distribution of demand nad industrial growth.

Fourth, many companies are affected by the financial crisis in the recent past and they may continue to pay their debts in the near future also. In order to avoid this they should have self supporting financial system and risk management plans to overcome such crisis. v) Fifth is that the companies should be flexible enough to face any kind of dynamism showed by public support systems which may stop or slower down their growth by imposing various regulations.

\section{DISTINGUISHED FEATURES \& CHALLENGES OF FINANCIAL INNOVATIONS.}

Financial innovations differ from other kinds of product developments. As per Ross and Allen and Gale financial innovations are facilitated by demand of the investors with specific set of cash flows. By segregating the cash flows of already existing securities the intermediaries can make huge profits in short run for themselves and helps in increasing social welfare. Financial innovations process can be distinguished in a better manner from other product developments like innovation of Apple of including laptop features and call phone in a single tablet only and also Tropicana's innovation of orange juice with calcium.

In this section we will project different issues that make financial innovations challenging:

1) The financial system in India is very huge and is interconnected in a very complex manner which can create positive as well as negative impact on the system. Consequently it will affect the social welfare of the economy.

2) Financial innovations are highly dynamic in nature. Changes in the structure of the financial innovations depend upon how the innovations are diffuse from early adopters to general users by using various marketing and promotional strategies.

3) Similar to regulations on various forms of innovations like pharmaceuticals, liquor industry financial innovations are also being imposed by government rules and regulations. Due to this kind of financial reforms the impact on the direction and speed of a financial innovation is very uncertain.

\section{I) Impact of financial innovations on social welfare of the economy}

The positive effects of an innovation can be measured as the rise or increase in social welfare by comparing the new set of choices with the ones which are already available. Such kind of framework would help in estimating whether the innovations are heading towards a boost in social welfare or these are a waste of monetary sources. Referring to the context of a discrete choice model, economists use data on actual attributes, prices, and sales to estimate the underlying demand and utility functions of the representative consumer.

For instance- Messaging while driving has led to a high rise in automobile accidents caused by distracted drivers - and had led to formations of regulations that discourages uses of such kind of innovations. The main challenge in evaluating the impact of financial innovations on social economy is that majority of its 
consequences is not very positive. On the other side of the ledger, many financial innovations address broad social needs. For example, venture capitalists provide monetary sources and expertise to help new firms to grow in the market; credit cards extend credit but also simplify the process of purchasing goods and services.

\section{II) The dynamic nature of financial innovations}

Innovations are assumed or indicated as a change by the economists and these innovations are studied as a process or cycle of change.

In 1992, Merton fabricated the term "innovation spiral" which describes the process that one financial innovation spawns the next. In a spiral, there is one innovation which consists of raw materials, building blocks for another. The innovation spiral can have both positive as well as negative follow on effects on the subsequent innovations.

Researches on innovations deals with process of diffusion that includes early adopters, early majorities, late majority and laggards. Financial innovations can fulfill the needs and demands of the investors for a set of cash flows and can contribute in social welfare. But the risks associated with these innovations can be very uncertain also. As soon as the investors realize that the new innovation is bagged with risks and uncertainties they will shift back to the safe traditional products. Due to this financial innovations can be held responsible for weakening the financial system.

\section{III) Relationship between regulation and innovation}

There is a very complex web relationship between innovations and regulations. Regulations and taxes acts as a impetus for financial innovations. Innovators are always keen to utilize the regulatory gaps, introduce new regulations. Each of these regulations gives rise to newer opportunities for more innovations. Alternatively, the regulatory system can become a pitfall for various reasons.

Firstly, major regulatory bodies have ordinances that are expounded by the institutions despite of functions. If a person wants to modulate equity exposures and that too in a broad manner, he has to coordinate between the Securities and Exchange Commission (SEC), Commodity Futures Trading Commission, banking regulators, and state insurance regulators initially

In absence of broad ordinances or functional jurisdictions, opportunities for regulatory merchandise through innovation will take place. Secondly, even a well-staffed, reasonably well paid, and highly talented regulatory agency is up against a world of potential entrepreneurs and innovators. Inevitably, regulation will tend to react to innovations, typically with a lag.

\section{EFFECTS AND SCOPE OF FINANCIAL INNOVATIONS}

The last decade have seen the emergence of many financial technologies and innovation like NEFT, Mobile Banking, E-banking among many other. But there exist a lot of room for improvement in the financial innovations and technologies as after the liberalization and globalization of Indian Economy, India has been trying to adapt to the turbulent financial market but there has not been any innovation in this area.

$\checkmark \quad$ India even lack the drivers of the financial innovation and technologies like Internet, computer that hinder the growth of adoption of these financial innovations as part of present way of doing business.

$\checkmark$ Countries should start spending more on financial innovation to get better growth opportunities and take advantage of the benefits of these financial innovations. The future of these innovations can be brighter if countries start spending more on these innovations.

There is a huge scope of financial innovations in our country. It has been observed that with time people are becoming more familiar to latest technologies like Internet that form a crucial part of these financial innovations and technologies and therefore, the scope of these innovations is becoming wider with time. Still, there exists a lot of scope in all areas for further improvement.

\section{Suggestions \& Recommendations}

The impact of financial innovations on the structure and behavior of financial markets are becoming more and more intense. The financial innovations like Venture Capital, microfinance and also various financial technologies like National Electronic Fund Transfer (NEFT), Mobile-Banking have a huge influence on the financial decision at individual and group level. Online share trading, E-banking have played a significant role in changing India. These financial innovations have brought many improvements in the financial environment of the country and have become a necessary part of the financial market to meet the needs of present global financial system and environment. But appropriate efforts should be taken to promote the innovations in the financial sector for continued growth and development that will lead the country to a path of becoming a superpower as these innovation and technologies drive economic growth and increase standards of living. 


\section{Conclusion}

The financial system of today is very dynamic and has high pace of innovations occurring in its component like financial markets, financial institutions, financial instruments and financial regulations. The financial innovations like NEFT, Mobile banking aim to enhance the efficiency of the financial system. By increasing the efficiency of financial system improvement in the economy and social wealth can be seen. There are many benefits of the financial innovation as they can save time and money of the users of these services. Therefore, the efficient usage of the financial innovation can modernize the present financial system making the transactions faster and easier than ever before.

These financial innovations and technologies have become vital part of the financial system of India and they have also brought many improvements in the financial environment of the country that is necessary to meet the competition and the needs of dynamic financial environment of the world. So, the role of the financial innovations in the present financial system of today should be properly understood to reduce the complexities and take full advantage of these innovations. The growth of the financial innovations in the financial sector should be promoted in every possible manner for continued growth and development as these innovation and technologies drive economic growth and economic development of the country.

\section{References}

[1]. Akhtar, M. A. Financial Innovations and Their Implications for Monetary Policy: An International Perspective. Basle: Bank for International Settlements, 1983 .

[2]. Anderloni, L., Bongini, P. (2009). Is Financial Innovation Still a Relevant Issue? In: L. Anderloni, D. T. Llewellyn, R. H. Schmidt (ed.), Financial Innovation in Retail and Corporate Banking, Cheltenham: Edward Elgar.

[3]. Allen, F., J. Barth and G. Yago (2012). Fixing the Housing Market: Financial Innovations for the Future, Wharton School Publishing-Milken Institute Series on Financial Innovations, Upper Saddle River, NJ: Pearson Education.

[4]. Cargill, Thomas F., and Gillian G. Garcia. Financial Deregulation and Monetary Control: Historical Perspective and Impact of the 1980 Act. Stanford,Calif.: Hoover Institution Press, 1982

[5]. Demirguc-Kunt, A. and E. Detragiache (1998). "Financial Liberalization and Financial Fragility," Working Paper 98/83, International Monetary Fund, Washington, D.C.

[6]. Drees, B. and C. Pazarbasioglu. (1995). "The Nordic Banking Crises: Pitfalls in Financial Liberalization?,” Working Paper 95/61, International Monetary Fund, Washington, D.C.Gubler,

[7]. Davis S, Haltiwanger J, Jarmin R, Lerner J, Miranda J. 2009. Private Equity, Jobs and Productivity. In Globalization of Alternative Investments Working Papers Volume 2: Global Economic Impact of Private Equity 2009, ed. Gurung A, Lerner J. New York: World Economic Forum USA, 2009, pp. 25-44

[8]. Goetzmann W, and Rouwenhorst G, ed. 2005. The Origins of Value: The Financial Innovations that Created Modern Capital Markets. New York: Oxford University Press

[9]. Henderson, BJ and ND Pearson (2011), "The dark side of financial innovation: a case study of the pricing of a retail financial product", Journal of Financial Economics, 100:227-247.

[10]. Jameson M, Dewan S, Sirmans C. 1992. Measuring Welfare Effects of "Unbundling" Financial

[11]. Innovations: The Case of Collateralized Mortgage Obligations. Journal of Urban Economics, 31: 1-13

[12]. Llewellyn, D. T. (2009). Financial Innovation and the Economics of Banking and the Financial System. In: L. Anderloni, D. T. Llewellyn, R. H. Schmidt, Financial Innovation in Retail and Corporate Banking. Cheltenham: Edward Elgar.

[13]. Lumpkin, S. A. (2010). Regulatory Issues Related to Financial Innovation. OECD Journal: Financial Market Trends, 2009(2), 91121

[14]. Mullineux, A. W. (2010). Financial Innovation and Social Welfare. Journal of Financial Regulation and Compliance, 18(3), 243256.

[15]. Mollica, M. and L. Zingales (2007). "The Impact of Venture Capital on Innovation and the Creation of New Business," Working Paper, University of Chicago.I

[16]. OECD (2003) Creativity, Innovation and Economic Growth In The 21st Century. Business and Industry Advisory Committee to the OECD.

[17]. Pierce, James L. "Did Financial Innovation Hurt the Great Monetarist Experiment?" American Economic Review 74 (May 1980), 392-96.

[18]. Reinhart, C., and K. Rogoff (2009). This Time is Different: Eight Centuries of Financial Folly, Oxford and Princeton: Princeton University Press.

[19]. Rose, P. S., Marquis, M. H. (2009). Money Market and Capital Market, Financial Institutions and Instruments in a Global Marketplace. New York: McGraw Hill.

[20]. Z. J. (2010). Instruments, Institutions and the Modern Process of Financial Innovation. Obtained from http://ssrn.com/abstract= 1608409. 